\title{
Analysis of Natural Resource Management, Quality of Tourist Attractions, Visitor Satisfaction and E-WOM Towards Tourism-Based Community Empowerment
}

\author{
Yuni Astuti $^{1} \quad$ Tita Deitiana $^{2} \quad$ Niken Purbasari $^{2} \quad$ Trival Apriadi $^{1} \quad$ Srie Poerbowati $^{1}$ \\ 1.Universitas Mercu Buana, Indonesia, \\ 2.STIE Universitas Trisakti, Indonesia
}

\begin{abstract}
In general, this study examines the sustainability of business and tourism with the topic of study is to build a model of tourism-based community empowerment in Sari Ringgung Beach, Tegal Mas Island, Bandar Lampung. More specifically, this study aims to analyze the Governance of Natural Resources, Quality of Tourist Attractions, Visitor Satisfaction and E-WOM Towards Tourism-Based Community Empowerment. The population of this study is traders in Sari Ringgung Beach, Tegal Mas Island with a total sample of 65 traders. The data analysis method uses Structural Equation Model-Partial Least Square (SEM-PLS). The research output is expected to be able to publish articles in international journals. The sampling method uses the saturated sample method. Data collection methods using survey methods with research instruments is a questionnaire. The results showed that Natural Resource Governance had a significant positive effect on Community Based Tourism Empowerment.
\end{abstract}

Keywords: Governance, Quality, Satisfaction, E-WOM, Empowerment

DOI: $10.7176 / \mathrm{JMCR} / 69-05$

Publication date:July $31^{\text {st }} 2020$

\section{INTRODUCTION}

The Bandar Lampung city government is developing the tourism potential of the beach, including Sari Ringgung Beach - Tegal Mas Island, which is starting to be crowded with visitors located on Way Ratay 14 in the village of Sidodadi, Teluk Pandan, Pesawaran Regency. Sari Ringgung Beach - Tegal Mas Island was inaugurated in 2014, undergoing renovation and development to date, including entrance fees, parking fees. The facilities provided are also adequate such as bathrooms, food and beverage stalls, rental of snorkeling equipment at affordable prices. The beach is open from 06.00 to $17.00 \mathrm{WIB}$, the road access is well paved, no harm. Attractions in Sari Ringgung Beach, Tegal Mas Island are Floating Mosque, Timbul Sand, Snorkeling Spot, Swimming and Playing Spot, Pondok and Gazebo.

According to the results of observations and initial research interviews with Ms. Yanty Rizal 2019, the manager of Sari Ringgung beach, Tegal Mas Island, is the existence of Sari Ringgung beach, Tegal Mas Island, which is very potential for developing tourism-based community empowerment. Besides the condition of the community before there is management (social, economic, tradition and culture) is still irregular and tends to be uneven in these aspects. After the management was carried out, the people around the coast were moved to take part, the people initially unemployed now have jobs, for example opening a food stall selling drinks, souvenirs, parking attendants, boat builders and so on, so as to improve the standard of living of the community.

According to Okazaki (2008), indigenous peoples previously initiated community-based ecotourism projects. To be sustainable, natural resource management is needed, so that community-based tourism can go down to the next generation (Knigt and Cottrell (2016).

Based on the results of research Resnawaty (2016) coastal communities have the weakness of the lack of development of skills change from fishing communities to tourism communities, as well as the results of research Akbar (2018) the lack of Human Resources in terms of education becomes a problem for the development of local communities. According to Dodds, et al (2018), Pramanik, et al (2019) that community-based tourism can reduce poverty, improve quality of life and increase income despite obstacles in achieving it.

The quality of tourism in an area is one of the determining elements in attracting tourists to come to a location. The quality of attractions integrated with facilities, infrastructure, transportation and services attract tourists. Provided mosque / musholla for Muslim tourists including ablution places and small rooms (Hasan, et al, 2015).

Introduction to tourists in a region is very easy to obtain through E-WOM, the problem is that E-WOM about Sari Ringgung Beach, Tegal Mas Island is not yet known by the surrounding community, so good comments don't spread throughout the country, even in the whole world. These are the phenomena we got at Sari Ringgung Beach, Tegal Mas Island, Bandar Lampung. Why Sari Ringgung Beach Tegal Mas Island has not been able to increase the income of the local community.

Based on previous research and the results of interviews with managers and the local community, we would like to conduct research on the management of Natural Resources, the quality of tourist attractions, visitor satisfaction and E-Wom to support the empowerment of the tourist community on Sari Ringgung Beach, Tegal 
Mas Island.

The novelty of this research is to increase community empowerment naturally by managing the natural environment to increase the empowerment of the tourist community. The contribution of this study examines the sustainability of business and tourism with the topic of study is to build a model of tourism-based community empowerment in Sari Ringgung Beach - Tegal Mas Island, Bandar Lampung. More specifically, this study aims to analyze the Governance of Natural Resources, Quality of Tourist Attractions, Visitor Satisfaction and E-WOM Towards Tourism-Based Community Empowerment.

\section{LOGICAL FRAMEWORK AND HYPOTHESES}

a. Relationship of Natural Resource Governance and Community Empowerment Travel Based.

In etymology governance means a process of reactivating or reviving. The governance referred to in this study is an attempt made to create an efficacy on certain objects so that they have more value and revive existing functions or potentials (Wongso, 2017).

The definition of governance is an attempt to re-manage an area that was once vital or alive, but has declined, with the aim of providing a more productive new life that is able to make a positive contribution to the social, cultural and economic life of the community (Wongso, 2017). According to Nurdin's research results (2016), an island is worth developing as a community-based tourist destination. Also the research results of Nurhidayati and Fandeli (2012), in the development of Agro-tourism strengthened the local community. Based on the theory and research results above, the first hypothesis proposed in this study is

H1: Natural Resource Governance has a positive effect on Community Based Tourism Empowerment

b. Relationship between the Quality of Tourist Attractions and Community Empowerment Travel Based

The quality of tourist attractions according to Sugiama (2004) includes five factors, namely a). Safety needs, b). Comfortable feeling needs, c). The quality of the presentation of tourist information,

d). Completeness of quality tourist facilities, e). Level of communication skills of officers.

According to the results of Wijono's research (2014), the dominant factors affecting visitor satisfaction are parking spaces, souvenirs and SAR. And the results of Sunarti's research (2018), show that physical motivation has a dominant influence on visiting decisions compared to social motivation and fantasy motivation. Feriyanto et al (2019) there is a relationship between attractiveness, trust, service quality, positive attitude, intention to visit the tourist village. Based on the theory and research results above, the second hypothesis proposed in this study is: H2: The Quality of Tourist Places has a positive effect on Community Based Tourism Empowerment c. Relationship of Visitor Satisfaction and Community Empowerment Travel Based Kotler and Keller (2011) say that customer satisfaction is the level of one's feelings after comparing the performance of the product or service he feels with his expectations. Consumer satisfaction or dissatisfaction is the response to the evaluation of the discrepancy or disconfirmation between the previous expectation and the actual performance of the product or service felt after usage. The results of the research of Basiya and Rozak (2012), Cole (2011) Foreign Tourist Satisfaction has a positive effect on intention to visit again. Based on the theory and research results above, the third hypothesis proposed in this study is:

H3: Visitor Satisfaction has a positive effect on Community Based Tourism Empowerment.

d. Relationship of E-WOM and Tourism-Based Community Empowerment

According to Park et al (2011) in Mihaela (2014) Word of Mouth (WoM) is a person-to-person conversation between recipients that are considered not commercial by the communicator, about certain products, services or brands. But e-WoM is a different activity in reality.

E-WoM according to Wardiyastuti (2017) as a form of communication that develops from WoM electronically or with the use of the internet, which is better than personal selling or conventional advertising where consumers use the internet to share experiences after using products or services, or consumers can take advantage of people's experiences others to make a purchase. Both can be positive or negative, if positive suggestions can more encourage other consumers to make purchasing decisions, if negative suggestions make consumers more likely to make purchasing decisions.

According to Abubakar (2016) research, eWOM is positively related to travel intentions and goal attainment. Also the results of research Abubakar, et al. (2017), eWOM affect the intention to re-visit and increase the confidence to visit tourist areas. Based on the theory and the results of previous studies, the following hypothesis is made. Based on the theory and research results above, the fourth hypothesis proposed in this study is:

H4: E-WOM has a positive effect on Community Based Tourism Empowerment 
Conceptual frameworks and hypothesis development can be illustrated in Figure 1.

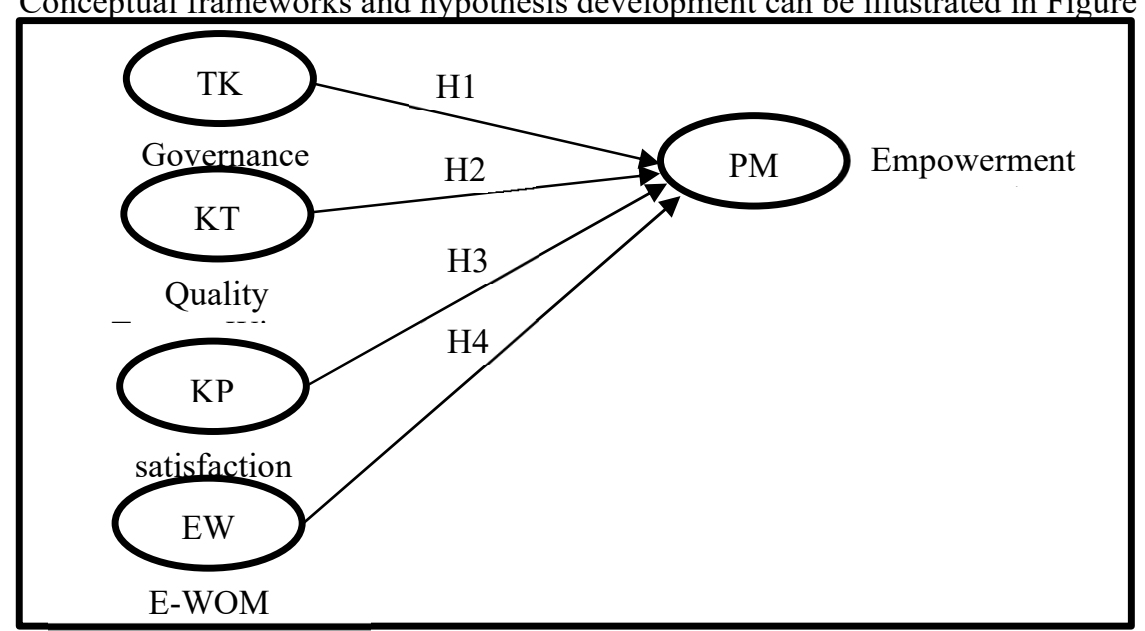

\section{RESEARCH METHODS}

This research is a causal associative study because it analyzes the increasing empowerment of tourism-based communities by increasing the SDA Management, Quality of tourist attractions, Visitor satisfaction and E-WOM. This research was conducted from November 2019 to May 2020

Measurement of Community Empowerment Variables, using Resnawaty measurement (2016), SDA governance using Wongso measurement (2016), Quality of tourist attractions using Sugiama measurement (2004), Visitor satisfaction using Kotler and Keller measurement (2008) and E-WOM using Al Hasan measurement and Setyaningtyas (2015). Based on the literature review, the concepts used in the measurement of each variable are detailed in indicators and items. Each item was evaluated using a 5 Likert scale category with answer categories from 1 as strongly disagree to 5 as strongly agree.

This research was tested in the scope of traders who sell at Sari Ringgung Beach Tegal Mas Island. With saturated sample techniques (Bungin, 2001 and Sugiyono, 2010) researchers distributed questionnaires to all traders who sold at Sari Ringgung Beach, Tegal Mas Island, as many as 65 traders, who were all members of the population. The data analysis method uses Partial Least Square (PLS).

\section{DATA ANALYSIS AND DISCUSSION}

a. Characteristics of Respondents

Characteristics of respondents indicate that there are more male sexes than women. Based on the age of most respondents at the age of 31-40 years. The last education was graduated from junior high school or equivalent. The most work time has worked more than 2 years.

b. Partial Least Square

1). Evaluation of Measurement Model (Outer Model)

a). Validity test

Testing validity in two ways, namely convergent validity and discriminant validity. According to Chin in Ghozali and Latan (2015) an indicator is said to have a good convergent validity if the loading factor value is greater than 0.7 .

The test results are shown in Figure 2. It can be seen that the loading factor value less than 0.5 is discarded, then analyzed again and the result is that the loading factor value is greater than 0.5 . 
Figure 2. Convergent Validity Test Results

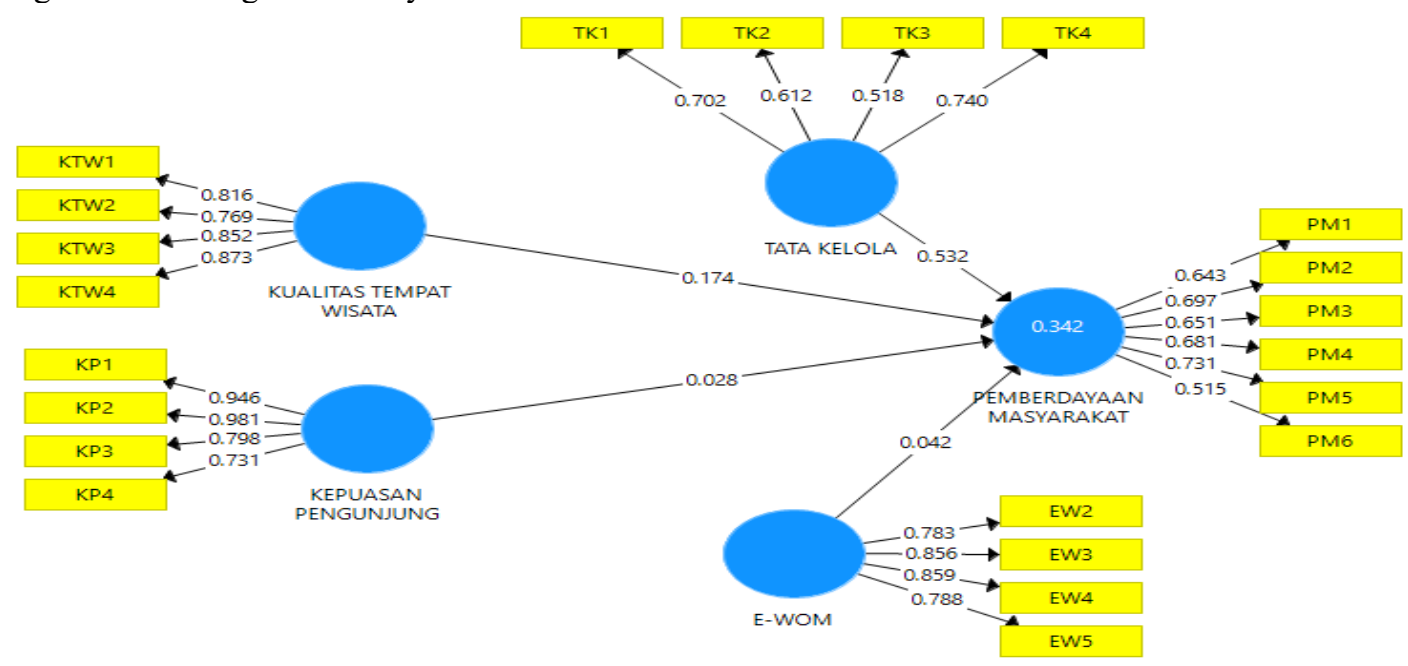

Source: Primary data from Smart PLS 3.0 (2020)

Discriminate validity is analyzed by comparing the value of the square root of AVE and the correlation value between constructors, that all square roots of each construct have a higher value than the correlation between other constructs. Thus it can be concluded that all measurement variables have good discriminant validity.

b). Reliability Test

The reliability test results (Table 1) were performed with Composite reliability and Cronbach Alpha. If all variable values have Composite reliability and Cronbach alpha $>0.7$, then they have good reliability or the questionnaire used has been reliable or consistent (Ghozali, 2014).

Table 1. Reliability Test

\begin{tabular}{|l|c|c|}
\hline \multicolumn{1}{|c|}{ Variable } & Cronbach Alpha & Composite Reliability \\
\hline E-WOM & 0,841 & 0,893 \\
\hline satisfaction & 0,917 & 0,925 \\
\hline Quality & 0,850 & 0,897 \\
\hline Community empowerment & 0,741 & 0,818 \\
\hline Governance & 0,527 & 0,741 \\
\hline
\end{tabular}

Source : Smart PLS, 2020

2) Evaluation of Structural Model (Inner Model)

a). Model Accuracy Test (Goodness of Fit Model Test)

To assess the accuracy of the model test by looking at the value of R Square Adjusted, it is seen that the adjusted Rsquare value has a low value for Tourism-based Community Empowerment, which is 29.9\%. This shows that the tourism-based Community Empowerment model has an incorrect model. This means that community empowerment is influenced by SDA Governance, Quality of Tourist Places, Visitor Satisfaction and E-Wom influences tourism-based Community Empowerment by only $29.9 \%$, while $70.1 \%$ is influenced by other than the four independent variables.

b). Hypothesis test

To find out the significance seen by comparing the significance value that occurs with a confidence level of 0.05 . If the significance value that occurs (indicated by the value of $\mathrm{P}$ value) $<0.05$, the hypothesis is accepted. The path coefficient results are shown in Table 2.

Table 2. Hypothesis Testing Results

\begin{tabular}{|c|l|c|c|c|c|}
\hline No & \multicolumn{1}{|c|}{ VARIABLE RELATION } & $\begin{array}{c}\text { Original } \\
\text { Sampel }\end{array}$ & $\begin{array}{c}\text { T- } \\
\text { Statistik }\end{array}$ & $\begin{array}{c}\text { P. } \\
\text { value }\end{array}$ & REMARKS \\
\hline 1. & E-WOM $\rightarrow$ COMMUNITY EMPOWERMENT & 0,042 & 0,227 & 0,820 & $\begin{array}{c}\text { Not } \\
\text { significant }\end{array}$ \\
\hline 2 & $\begin{array}{l}\text { SATISFACTION } \\
\text { EMPOWERMENT }\end{array} \rightarrow$ COMMUNITY & 0,028 & 0,167 & 0,868 & $\begin{array}{c}\text { Not } \\
\text { significant }\end{array}$ \\
\hline 3. & $\begin{array}{l}\text { QUALITY } \\
\text { EMPOWERMENT }\end{array}$ & 0,174 & 1,178 & 0,239 & $\begin{array}{c}\text { Not } \\
\text { significant }\end{array}$ \\
\hline 4 & $\begin{array}{l}\text { GOVERNANCE } \rightarrow \text { COMMUNITY } \\
\text { EMPOWERMENT }\end{array}$ & 0,532 & 5,243 & 0,000 & Significant \\
\hline
\end{tabular}

Source: Primary data from Smart PLS, 2020 
In Table 2 it can be seen that the effect of E-WOM on community empowerment is not significant, because its statistical $\mathrm{T}$ value is $0.227<1.96$ and its $\mathrm{P}$ values are $0.820>0.05$. Likewise, the effect of visitor satisfaction on community empowerment is not significant because the T statistic is $0.167<1.96$ and $\mathrm{P}$ values $0.868>0.05$.

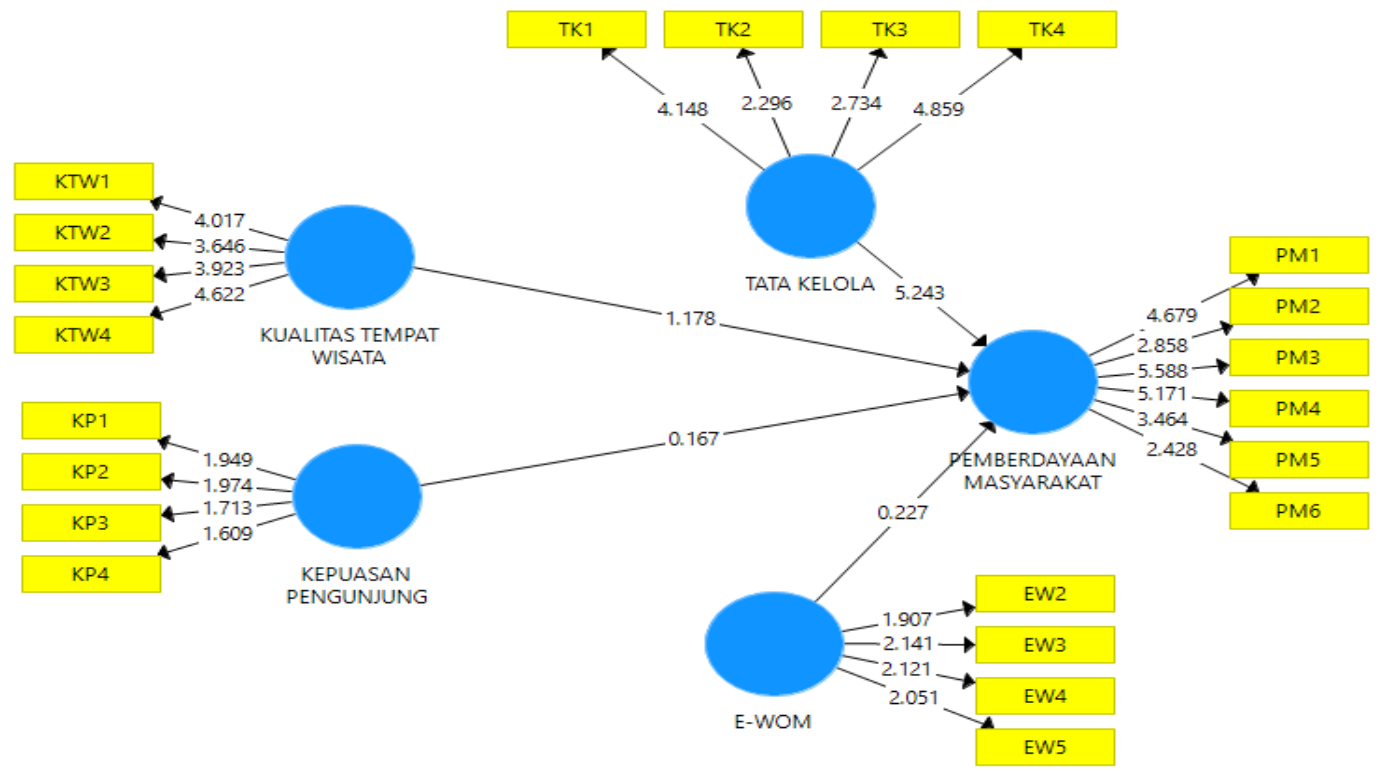

Source:: Primary data from Smart PLS 3.0 (2020)

Also the effect of the quality of tourist attractions on Community Empowerment is not significant because the Tstatistic value is $1.178<1.96$ and Pvalues $0.239>0.05$. While the Effect of Governance on Community Empowerment has a significant positive effect because its statistical $\mathrm{T}$ value is 5, 243>1.96 and $\mathrm{P}$ value 0,000 $<0.05$.

c. Discussion

1). Effect of Natural Resource Governance on Tourism-based Community Empowerment

The results of testing Hypothesis 1 proved to be acceptable, that the management of natural resources has a positive and significant effect on community empowerment based on tourism. When analyzed using loading factors that the development of objects and tourist attractions in Sari Ringgung Beach is rusty on Tegal Mas Island, such as the development of Lampung culture and creativity competitions with white sand material are the most dominant indicators in reflecting natural resource governance, so as to increase empowerment travel based community.

The results of this study can be explained using the theory in Wongso (2017), Definition of Governance is an effort to re-manage an area that was once vital or alive, but has declined, with the aim of providing a new life that is more productive that is able to make a positive contribution to social, cultural and economic life of the people

The results of this study also reinforce research that has been done previously, namely Nurdin (2016), Resnawaty, R (2016), Nurhidayati, S.E and Fandeli, C (2012), who found that the Governance of Resources increased, the empowerment of tourism-based communities also increased. Contrary to Astuti's research (2019), natural resource management does not affect community empowerment.

2). Effect of Quality of tourist attractions on Tourism-based Community Empowerment

Hypothesis testing results are not proven, hypothesis 2 is rejected, that the quality of tourist attractions does not significantly influence the empowerment of tourism-based communities. When analyzed using loading factors that the staff's friendliness, security and high comfort are not able to increase the empowerment of the tourism-based community in Sari Ringgung Beach, Tegal Mas Island.

The results of this study can be explained by using the theory of Sugiama (2004) that the quality of tourist attractions includes five factors, namely the need for security, the need for comfort, the quality of the presentation of tourist information, the completeness of quality tourist attraction facilities, the level of communication skills of officers, including the ability of officers in communicating with tourists.

The results of this study do not strengthen the research results of Sutawa (2012) and Okazaki (2008) that the quality of tourist attractions increases the empowerment of tourism-based communities. According to the results of Wijono's research (2014), the dominant factors affecting visitor satisfaction are parking spaces, souvenirs and SAR. And the results of Sunarti's research (2018), Nur et al (2019) where physical motivation has a dominant influence on visiting decisions compared to social motivation and fantasy motivation. Contrary to the results of Astini and Sulistiyowati's research (2015), the quality of service increases, so that community empowerment also increases 
3). Effect of Visitor Satisfaction on Tourism-based Community Empowerment

The results of testing the hypothesis were not proven, hypothesis 3 was rejected, that visitor satisfaction did not significantly influence the empowerment of the tourism-based community. When analyzed using loading factors that the high satisfaction about information on tourist areas and the existence of positive comments from the posting of images in the mass media are not able to increase the empowerment of the tourism-based community in Sari Ringgung Beach Tegal Mas Island.

The results of this study can be explained by using the theory of Kotler and Keller (2011) which says that customer satisfaction is the level of one's feelings after comparing the performance of the product or service he feels with his expectations. Consumer satisfaction or dissatisfaction is the response to the evaluation of the discrepancy or disconfirmation between the previous expectation and the actual performance of the product or service felt after usage.

The results of this study do not support the results of the research of Basiya and Rozak (2012), Foreign Tourist Satisfaction has a positive effect on intention to visit again. While the results of the study Suosheng Wang (2019) support the results of research in which visitor satisfaction does not affect the empowerment of tourism-based communities. Visitor satisfaction from previous visitor comments, as well as good picture posts that illustrate the situation of Sari Ringgung Beach, Tegal Mas Island, so that community empowerment remains unchanged.

4). Effect of E-WOM on Community Empowerment based on tourism

The results of testing the hypothesis were not proven, hypothesis 4 was rejected, that E-WOM did not significantly influence the empowerment of the tourism-based community. If analyzed using loading factors that the high EWOM about positive experiences of tourists and interesting comments are not able to increase the empowerment of tourist-based communities in Sari Ringgung Beach, Tegal Mas Island.

E-WoM according to Wardiyastuti (2017) as a form of communication that develops from WoM electronically or with the use of the internet, which is better than personal selling or conventional advertising where consumers use the internet to share experiences after using products or services, or consumers can take advantage of people's experiences others to make a purchase. Both can be either positive or negative, if positive suggestions are more able to encourage other consumers to make purchasing decisions, if negative suggestions are more likely to enable consumers not to make purchasing decisions.

The results of this study do not support the results of Abubakar (2016), Abubakar (2017), in which E-WOM can increase return visits to tourist areas that can increase the empowerment of tourism-based communities.

\section{CONCLUSIONS AND RECOMMENDATIONS}

a. Conclusion

Based on the previous description, it can be concluded, that Natural Resource Governance has a significant positive effect on Community Based Tourism Empowerment. While the quality of tourist attractions, visitor satisfaction and E-WOM has no effect on the empowerment of tourist-based communities.

b. Suggestion

Based on the discussion and conclusion, it can be suggested that the development of tourism objects as the most dominant reflection on the empowerment of tourism-based communities is the least responded by respondents, for this reason it needs to be improved, for example the utilization of natural potential, increasing environmental assets.

Suggestions for further research, it is necessary to do research related to environmental management, so that the world of tourism gets input for the improvement of its business managers, so that they are able to compete and increase tourism-based community empowerment.

Implications for the world of tourism must be made efforts to improve new life more productive, positive contribution to the community's economy, positive contribution Social life and positive contribution to culture.

\section{REFERENCES}

Abubakar, A.M (2016). Does eWOM Influence Destination Trust and Travel Intention: A Medical Tourism Perspective. Journal Economic Research 29(1) : 598 - 611

Abubakar, A.M et all.(2017). eWOM, Revisit Intention, Destination Trust and Gender. Journal ofHospitality and Tourism Management 31(2017): 220-227

Akbar, MA (2018). Development of Community-Based Cultural Tourism Village in Sade Hamlet, Rembitan Village, Central Lombok Regency. Faculty of Fisip Muhammadiyah Malang.

Astini, R and Sulistiyowati, I (2015). The Effect of Destination Image, Travel Mutivation and Service Quality on 
Visitor Satisfaction (Case Study on Muslim Archipelago Travelers at Carita Pandeglang Beach, Banten, Scientific Journal of Management and Business, 1 (3): 1-10

Astuti,Y and Widayati,C (2019). The Natural Resources Governance as a Moderation for the Effect of Natural Environment on Community Based Empowerment (Case study in Ringgung Beach Bandar Lampung). Journal of Economics and Sustainable Development, 10 (18) : 100 - 106

Basiya, R and Rozak, H.A (2012) Quality of Tourist Attraction, Satisfaction and Intentions of Foreign Tourist Return Visit. Journal of Tourism Dynamics XI (2): 1 - 12

Bungin, Burhan (2001). Social Research Methodology (Formats Quantitative and Qualitative). Airlangga University Press. Surabaya.

Cole, S (2011). Information and Empowerment: The Keys to Achieving Sustainable Tourism. Journal of Sustainable Tourism, 14 (6) : $629-644$

Dodds, R; Ali, A and Galaski, K ( 2018 ). Mobilizing knowledge: determining key elements for success and pitfalls in developing community-based tourism. Current Issues I Torism, 21(13) : 1547-1568.

Feriyanto, Nur; Kot, Sebastian; Sugandini, Dyah (2019). The Development of Community Based Tourism: from Attractiveness to Loyalty. Bucharest $2: 393$

Ghozali, I. (2014). Structural Equation Modeling Metode Alternatif dengan Partial Least Squares. Semarang : Universitas Diponegoro.

Knight, D.W and Cottrell, S, P. ( 2016 ). Evaluating tourism-linked empowerment in Cuzco, Peru. Annals of Tourism Research, $56: 32-47$

Kotler, P and Keller, K, L (2011). Marketing Management . Erlangga Jakarta

Nur, F; Sebastian,K; Diah, S; Muafi ( 2019 ). The Development of Community Based Tourism: from Attractiveness to Loyalty. Bucharest, $20: 393-399$

Nurdin (2016). Strategy for Community-Based Tourism Development on the Island Samalona, Makassar. Jump Journal 3 (1): 175 - 189

Nurhidayati, S.E and Fandeli (2012). Application of Community Based Principles Tourism (CBT) in Agro Tourism Development in Batu City, East Java. Journal of Public Administration Network 4 (1): 36 -46

Okazaki, E (2008). A Community-Based Tourism Model: Its Conception and Use. Journal of Sustainable Tourism, $16(5): 511-529$

Pramanik,P,D; Ingkadijaya, R dan Achmadi M ( 2019). The Role of Social Capital in Community Based Tourism. Journal of Indonesian Tourism and Development Studies. 7(2) : 62 -73

Resnawaty, R (2016). Community Practice Strategies in Community-Based Tourism Development. Social Work Journal, $6(1): 1$ - 153

Sugiyono.2010. Qualitative Quantitative Research Methods and R \& D. Alfabeta. Bandung.

Sunarti, D.R.M.M (2018). Effect of Motivation on Visiting Decisions Tourists at Wonorejo Mangrove Eco Tourism Surabaya. Journal of Administration Business (JAB), 55 (1): 196-203.

Sutawa, G.K. (2012). Issues on Bali Tourism Development and Community Empowerment to Support Sustainable Tourism Development. Procedia Economics and Finance 4 ( 2012 ) 413 - 422

Wang,S (2019 ). Residents' perceptions of community-based disaster tourism: the case of Yingxiu, China. Asia Pacific Journal of Tourism Research , 4 (7) : $669-678$

Wijono, D (2014). Visitor Satisfaction Level Kuwaru Beach Tourism Object Sanden Bantul Yogyakarta. Journal of Maksipreneur, IV (1): 22 -35

Wijono, D (2014). Visitor Satisfaction Level Kuwaru Beach Tourism Object Sanden Bantul Yogyakarta. Journal of Maksipreneur, IV (1): 22 -35

Wongso, J (2017). Revitalization Strategy of Bukittinggi City Center Area. Online journal / Department of Architecture, Faculty of Civil Engineering and Planning, Bung Hatta University, Padang.

$\mathrm{Xu}, \mathrm{H}$; Jiang, F; Wall, G dan Wang, Y ( 2019 ). The evolving path of community participation in tourism in China. Journal of Sustainable Tourism, 27 (8) : 1239 - 1258

Yanes, A; Zielinski, S, Cano, M,D; Kim, S ( 2019 ). Community-Based Tourism in Developing Countries: A Framework for Policy Evaluation. Sustainability, 11(9), 2506-2516

Zielinski , M, Diaz Cano and Seong-il Kim (2019). Community-Based Tourism in Developing Countries: A Framework for Policy Evaluation. Sustainability, 11(9). 